University of Nebraska - Lincoln

DigitalCommons@University of Nebraska-Lincoln

20th \& 21st Century French and Francophone Modern Languages and Literatures, Department Studies International Colloquium

\title{
Reading Antelme with Levinas: Recreational Activities in Concentration Camps
}

Arwa Reda

Follow this and additional works at: https://digitalcommons.unl.edu/ffsc2020

Part of the Comparative Literature Commons, French and Francophone Literature Commons, and the Other French and Francophone Language and Literature Commons

This Article is brought to you for free and open access by the Modern Languages and Literatures, Department of at DigitalCommons@University of Nebraska - Lincoln. It has been accepted for inclusion in 20th \& 21st Century

French and Francophone Studies International Colloquium by an authorized administrator of DigitalCommons@University of Nebraska - Lincoln. 
Arwa Reda, University of Minnesota

doi: 10.32873/unl.dc.ffsc.08

20th \& 21st Century French and Francophone Studies International Colloquium, University of Nebraska-Lincoln, March 26-28, 2020.

https://digitalcommons.unl.edu/ffsc2020/

Copyright @ 2020 Arwa Reda

Reading Antelme with Levinas: Recreational Activities in Concentration Camps

Mieulx est de ris que de larmes escripre,

Pource que rire est le propre de l'homme.

- François Rabelais, Gargantua, «Aux lecteurs »

What do we live for, if it is not to make life less difficult for each other?

- George Eliot, Middlemarch bk.8, ch.72

Whether humanities humanize or not has always been a question that gathered both its proponents and opponents. Between those who confirm the statement and those who adamantly repudiate it, history has provided instances that simultaneously bear out both positions. Rather than attempting to prove or to deny the humanizing aspect of language and literature, this article looks at the matter from a different angle. Instead of the either-or argument, I propose the how as a bedrock of understanding the way humanities can humanize. Many camp survivors extolled what could be qualified as a redemptive force of language and literature. A force that helped resuscitate their sense of self and vivify anew their human dignity. Understanding the potential of this force is what this article attempts to do. How can language and literature become a redemptive force? How can the two construct a channel through which one could elevate oneself 
from the petty survival-based, self-centered concerns to intersubjective relations with others? To examine these questions closely, I will do a close reading of an episode in Robert Antelme's L'Éspèce humaine, where he recounts the effects of literature on camp inmates. In my close reading, I am drawing on Emmanuel Levinas's ethical disquisition on intersubjective relations, in particular the concept of suffering in relation to the self and the manner with which speech dynamics factor into the forging of these relations through sharing a "common world" to reprise Hannah Arendt's concept. I am suggesting that it is only through sharing that language and literature could become a medium through which one's sense of humaneness and selfhood is regained, which, in turn, helps condition the circumstances to reconnect with the other.

During the second World War, Antelme worked with the French resistance, was arrested and deported to the Nazi working camps of Buchenwald, Gandersheim, and then Dachau. In the camps, Antelme observed the fruition of a hierarchical, Machiavellian system that sought to dehumanize prisoners and instrumentalized the possible ways to pit inmates against each other in their daily struggle to survive. Many a time, these methods succeeded in tearing down what was left of inmates' dignity, propelling them to withdraw each into himself. In the process, they forgot about others' suffering in the same crucible, all of which led to an egotistical attitude which in turn created a profound gulf between inmates. In their attempts to fend for their own survival, many in the camps ended with a dreadful sense of alienation both from themselves and others. Their suffering reduced them to sheer wreckage: famished, scared, and haunted by basic and pressing survival needs, they found themselves isolated in their daily struggle to survive.

Inner and physical wounds as well as the value of sharing or lack of it are key when it comes to answering questions like: How can suffering bring men to such an attitude? What in 
them was broken that brought about this state of indifference and detachment? Levinas theorizes that the anguish physical suffering produces originates from the impossibility of escaping it. The person suffering is at the mercy of this painful sensation: « Il y a dans la souffrance une absence de tout refuge [....] Elle est faite de l'impossibilité de fuir et de reculer. Toute l'acuité de la souffrance est dans cette impossibilité de recule. Elle est le fait d'être acculé à la vie et à l'être » (Le Temps et l'autre 55-56/69). The idea of becoming "acculé [backed up against]" is revelatory in this context. The person feels cornered in a situation from which there is no escape. The result is a descent into the tenebrous depths of oneself, where one finds him/herself totally lost. Consequently, instead of commiserating with others in the same predicament, the subject turns away from them, inward to him/herself. In such a situation, where suffering inscribes its indelible mark on the body and maims the mind, one becomes a prisoner to one's own fears, where the only concern becomes one's own survival.

However, amidst the grim camp circumstances, Antelme recounts how a teacher, Gaston Riby, exercised a strong determination to rekindle the dormant humane element within his fellow inmates by organizing what he would name "séance[s] récréative[s]," during which they would recite poetry and sing (Antelme 209). These gatherings helped inmates feel at least a modicum of esprit de corps, and as a result, their sense of commiseration with one another's ordeals was gradually revived. This covert way of resistance was an important survival strategy, one with no violent expression but rather a determination to keep the human spirit glowing. Meaningful speech proves to be a tool which enables the inmates to brush off the thick layer of rust and dust covering their mental and sentimental capacities, allowing them, in consequence, to assert their own merit as human beings capable of sound judgement and social solidarity. Through 
meaningful speech, Riby encouraged men to find their own selves as a way to escape the slings and snares of helplessness and dejection: "il faut parler" he reiterates.

But for Riby's message to make its way to other inmates in the camp block, it has to undergo a trying, circuitous process. During forced labor, Riby's message is conveyed in bits and pieces, passes from one man to another, meddled and disjointed. Antelme details, « les phrases étaient hachées par le rythme du travail à la pioche [... . Et c'était trop fatiguant de tenir une véritable conversation » (Antelme 210). Nevertheless, the civil supervisor, acting on behalf of the SS authority “ne pouvait pas empêcher les mots de passer d'un homme à l'autre ” (210). To be sure, sentences could be "hachées" a word that both connotes the disjunction, nay discontinuation, of the message and the sense of being cut with the blows of an axe. While the rhythm or the pace of pickaxe work renders the message less intelligible, the sentences are nonetheless transmitted and the inmates glean the purport of Riby's message. There is a hint of a tug of war between the toiling in the earth and the transmission of words. The rhythm of manual work forces Riby's message to be reduced in snatches which, unlike the hammering rhythm of the axe, are fragmented and mostly incoherent. Yet its unintelligibility preserves or rather encodes it so that the civil supervisor cannot get wind of its content.

The power of language assumes the forestage and sidelines that of the SS. The manner in which Riby's message is communicated corroborates the persecutor's failure to prevent the inmates from finding a way to re-gather themselves:

[U]n langage se tramait, qui n'était plus celui de l'injure ou de l'éructation du ventre[ .... Celui-là creusait une distance entre l'homme et la terre boueuse et jaune, le faisait distinct, non plus enfoui en elle mais maitre d'elle, maitre aussi de $s$ 'arracher à la poche vide du ventre. 
In "un langage se tramait," the metaphor of weaving points to the formation of some sort of a new spoken language which goes beyond the howls of empty stomachs, the tensions which ensue and culminate in insults, name calling, or unintelligible screams. Instead of these deformed forms of communications, the inmates, by virtue of Riby's call, can gradually forge meaningful speech, one that is kind and reassuring. A speech which has the power to widen the distance — and with it the difference — between men and "la terre boueuse et jaune." A distance that brings to the fore men's irreducible quality as human beings. The second metaphor is that of digging; the rich semantic field of the word "creuser," allows two important connotations that factor here: the literal "digging the tunnel" and the figurative, that is the widening of the gap as in "creuser une distance entre l'homme et la terre." It is through the latter that Antelme paints a positive portrait of the man who distinguishes himself from earth in the sense that meaningful speech—or at least attempted one - helps widen the distance between men and hunger. Meaningful speech, be it in rhythm with the clanking of "la pioche," opens a route for men to escape the growlings of "la poche vide du ventre." In using the same verb, "creuser," to designate two different levels of meaning, Antelme highlights the inmates' keen efforts to arrive at a definitive form of identification. It is also the first step to liberate themselves from the gnashing fangs of selfishness and egotism that readily results from being at the beck and call of the need to survival.

But how to define meaningful speech? Two terms that can help us probe further the dynamics of speech utterances and its bearing on intersubjectivity would be the Saying [Dire] and the Said [Dit]. According to Levinas, while Saying is more of an action-based concept, the Said relies upon the premise of language as apophantic, that is, the potential to verify the veracity of the statement. The difference between the Saying and the Said can be explained in the 
correlation between the verb and the noun in a statement or any verbal utterance (Ricœur 7). The Said is pertinent to the noun's veracity, while the Saying designates an action verb, an anteriority of intention which precedes the veracity of the Said. It follows that the Saying concerns itself with the other: the subject recognizes the presence of the other, turns his/her attention towards the other, and acknowledges this person by addressing oneself to him/her. Nevertheless, one cannot have Saying without Said; the Said is a priori to the Saying and yet the Saying is concerned in weaving a relationship with the otherness of the other (Hors sujet 211).

In the séances récreatives, the Saying is writ large in the literature and poetry shared and recited. Antelme remarks that these literary gatherings "pouvaient être l'occasion de rire, ou en tout cas de se distraire" (209). Literature in the form of songs, poetry, and storytelling assumes here a double role: on the one hand, it becomes a means for diversion that both amuses and entertains, thus motivating men to engage. On the other, it reminds them of their full-fledged life before the camp, thus reviving inside them a yearning to become themselves again, or to regain at least some of their lost selfhood (ipseity). The memories awakened by poetry and song recall to their minds who they were prior to being imprisoned in these dire circumstances. In other words, these gatherings opened the doors for the inmates to reconnect with their humane side, making their existence once again meaningful.

Diversion is indeed an essential part in the process, yet it is only the first step. These gatherings were not simply meant to be a hebetudinous surcease of suffering where men forgot momentarily their misery and ailments. They were rather a manner by which inmates could manifest human resilience against constant attempts by their persecutors to suppress their minds and reduce them to brute animals. 
What can qualify as a degeneration to an insignificant and shapeless entity shows its ugly face in the form of an almost unintelligible form of speech that oozes out and defies at once the purposes of the Saying and the Said. It is a form of speech that has lost its quality to vehicle noble ideas: in lieu of being a production of the mind and a venue to nourish the civility and decency of men, the function of speech under the back-breaking yoke of physical and psychological pain in the camps has become akin to manducation and deglutition of food.

Speech in Nazi concentration camps became emptied of rich meanings, of beauty, and of eloquence; camp speech transformed from a means for men to express themselves in a civilized fashion into nothing more than a disgusting emesis. Antelme demurs, "Les phrases se suivaient, se contredisaient, exprimaient une certaine éructation de la misère ; une bile de mots [....] le type se vidait [...] L'Enfer, ça doit être ça, le lieu où tout ce qui se dit, tout ce qui s'exprime est vomi à égalité comme dans un dégueulis d'ivrogne." For Antelme, such lack of form, meaning, and intellectual value in speech is symptomatic of the ignominious state to which the inmates have been reduced. It represents the incarnation of the pit into which men were ensnared and thus prevented from transcending their mundane needs. This emetic form of speech finds its echo in the muddy and yellow earth the detainees are forced to dig and in turn stands in stark contrast with that of the poems that they recite during the gatherings organized by Riby as Bruno Chaouat astutely remarks:

To human regression to the undifferentiated humus (the "yellow, muddy earth"), to this humiliation that reduces man to his organs and language to inarticulate voice, poetry responds with form. Reading poetry, as ordering and composing [. . .] amounts to no less than a restoration of the human face and dignity [....] The Nazi fantasy was to relegate the detainees into the world of the inorganic and the formless. Poetry stands as the resistance of organized life to this fantasy. (9) 
Poetry in this case presents itself as a way to resist the transformation of man into a being without a definitive form, a being indistinguishable from the yellow and muddy earth where he toils. Furthermore, meaningful language weaves together intersubjective relations and this intersubjectivity becomes possible only by dint of meaningful speech—a form of sociability that enables one to come out of the battered chrysalis of the self and to start thinking and then caring for others (without totally forgetting one's self). Levinas opines that when the subject is riveted on the soi [self,] that is one's material existence, the subject becomes blind and insensitive to others. It throws one into the dark abyss of solitude making one attached to one's own material existence. When their stomachs are empty, men's extreme suffering imperils the good within and amongst themselves, ideas become a luxury that does not pertain anymore to the miserable life in the camp, and one becomes imprisoned behind the bars of the self, deprived from the meaningful interaction with the other, lost in the quagmire of one's own materiality, and thus inhibited from even actualizing selfhood.

However, during the literary gathering, Antelme recounts, the chains of the self start to dissolve. At a certain moment men transcend their hunger and pain. By virtue of sharing poetry, the inmates become less mired in the sordid reality of the camp - at least momentarily. They transcend it by preoccupying themselves with what is important for the survival of their humaneness. In escaping the obsession with food, however briefly, each of them starts to find both himself and the ties that link him to his comrades, which in turn constitutes the first step to initiating a relation with the other. For one's humaneness is not complete without forging a genuine solidarity and responsibility of one's own kind. To salvage this sense of mutual responsibility is ipso facto to escape the dehumanizing traps of the SS. In finding meaning 
through sociability, one can endure in the face of pain, and in finding meaning through sociability one finds a piece of oneself.

Such sociability, or the "common world" as Hannah Arendt would have it, transcends the temporal and the spatial limits of human existence and joins us with others through common interests (Arendt 95). It enables us to perceive events not only from our perspective, but also from that of others' going through them. The work of art, be it literature, poetry, or an artifact is an instantiation of this common world. It does not submit to the laws of consumerism of pecuniary value; its value rests on a transcendence that constructs an enduring continuity. Man is the initiator of the common world, a space where shared human interests take shape. Transcendence through sharing the work of art is what Antelme witnesses at the end of this literary gathering.

At the end of the "séance," a movement towards light is perceptible, manifested in the radiant smile drawn over the inmates' haggard faces. Antelme bracingly describes this moment of equanimity, «La lumière était venue dans le block. Le poêle avait été pour un moment abandonné. Il n’y avait pas d'épluchures dessus. Les copains étaient groupés autour du tréteau. . . . Si quelqu'un à ce moment-là était entré dans le block, il en aurait eu une vision étrange. Tous souriaient » (Antelme 214-215 ; my emphasis). For a moment, light shines and spreads causing men to forget about the cook stove, where they race to cook vegetable peelings. The smile becomes a metonym for the effort done on their part to liberate themselves from the fetters of sheer materiality, of being riveted to their own selves. This moment — be it fleeting — marks a glimmer of hope into human capacity to transcend trying situations through shared experiences with others. 
During these gatherings, with poems recited and songs beautifully performed, the inmates experience diversion and comfort. They join each other in the shared goal of creating good moments using a language that spoke both to and for them. The intrinsic value of the inmates' humanity is established and the bridge of fraternal relationship rebuilt. They reunite by their love for literature, by memories, and by imagination. The quality of sharing literature uplifts them from that which sustains only the body to that which nourishes the mind and animates the imagination.

\section{Works cited}

Antelme, Robert. L'espèce humaine. Éditions Gallimard, 1957.

Arendt, Hannah. Condition de l'homme moderne, Pocket Agora, 1983.

Chaouat, Bruno. Unpublished speech. “Art, Poetry After Auschwitz,” in colloquium "Performances and Performatives of the Holocaust: French and North African Acts of Resistance, Collaboration, and Testimony" May 1, 2009. UCLA.

Levinas, Emmanuel. Le temps et l'autre. Presses Universitaires de France, 1989.

Levinas, Emmanuel. "Langage quotidien et rhétorique sans éloquence” Hors sujet, Fata Morgana, 1987.

Ricoeur, Paul. Autrement : Lecture d'autrement qu'être, ou, au-delà de l'essence d'Emmanuel Levinas. Presses Universitaires de France, 1997. 